\title{
Navorsingsartikels/Research articles
}

\section{The significance and insignificance of Clive Bell's formalism 1}

\author{
Johan Snyman \\ Dept. of Philosophy \\ Rand Afrikaans University \\ JOHANNESBURG
}

\begin{abstract}
('live Bell coined the phrase significant form. The way he initially defined the phrase and the way he implemented it were wo different matters. In this article Bell's procedure is analysed as a characteristic of late modernist aesthetics, i.e. an attempt to come to terms with the challenge of the radically new' in art. It is suggested that one should bear in mind that formalism in this sense is a theory of artistic material which explains how meaning is communicated and perceived through non-discursive qualities of the artistic material. That is the relevance of Susanne K. Langer's reinterpretation of Bell's phrase.
\end{abstract}

\section{Introduction}

Clive Bell's aesthetics does not make for profound reading. Why bother then? The least one can say is that Bell contributed towards the modern aesthetic vocabulary by coining a phrase that has since become a cliché or hackneyed for that matter, viz. significant form. On the other hand, if one reflects from a distance on the Wirkungsgeschichte of Bell's plirase as well as on the Wirkungsgeschichte of the problem he wanted to solve, significant form has an intriguing logic. Significant form as an aesthetic category has spawned quite a generation of related concepts, from Clive Bell to Susanne K. Langer's unconsummated symbol, up to Nelson Goodman's languages of art (Goodman, 1976), Peter

\footnotetext{
1 A revised version of a paper read at a 2 nd International Symposium on Formalism, organized by the Slovenian Society of Acsthetics in Ljubljana, 14 - 17 May 1992. I thank Paul Crowther, Ales Erjavec and Richard Woodficld for critical comments on the original version.
} 
Kivy's physiognomy of musical expression (Kivy, 1980) and perhaps Arthur C. Danto's transfiguration of the commonplace (Danto, 1981), as well as David Summers' conceptual image (Bryson et al., 1991:231-259). It has distant relationships with Alois Riegl's Kunstwollen and Julius von Schlosser's Kunstsprache. As such one is justified to say that significant form constitutes one episode in the narrative of the history of art as an autonomous and intellectual discipline, i.e. to explain the development of art forms and styles not with reference to the biographies of artists, but in terms of concepts related to the arts themselves. A further merit of the notion of significant form is that it creates an apparatus for analysing and explaining the reception of works of art, especially when new works of art tend to upset well-established patterns of aesthetic behaviour.

Perliaps that is crediting Bell for too much, for he did not talk of 'reception of works of art' but of 'appreciating art'. Neither did he refer to 'upsetting well established patterns of aesthetic behaviour', but rather to something akin to unrecognized reappearances of past great moments of the history of art. But that is the sense I propose to make of his 1914 book, simply titled $A r t$, otherwise described by himself in a 1949 foreword as full of "exaggerations, childish simplifications and injustices" (1987:xv). My approach entails that I shall do some close reading of Bell's $A r t$, but with the wisdom of historical hindsight. I am very much interested in the loose strands of his argument, as I propose to read them as indications of unsolved modenist issues. Without attempting a problemgeschichtliche genealogy of the notion of significant form, I want to argue that Susanne K. Langer's interpretation and reworking of Bell's phrase contributes significantly to formalism as a tenable aesthetic theory.

\section{Bell's significant form}

What does Bell's phrase significant form entail? I quote Bell's now famous description at length:

For either all works of visual art have some common quality, or when we speak of 'works of art' we gibber. Everyone speaks of 'art', making a mental classification by which he distinguishes the class 'works of art' from all other classes. What is the justification of this classification? What is the quality common and peculiar to all members of this class? Whatever it be, no doubt it is often found in company with other qualities; but they are adventitious - it is essential. There must be some one quality without which a work of art cannot exist; possessing which, in the least degree, no work is altogether worthless. What is this quality? What quality is shared by all objects that provoke our aesthetic emotions? What quality is common to Sta Sophia and the windows at Chartres, Mexican sculpture, a Persian bowl, Chinese carpets, Giotto's frescoes at Padua, and the mas- 
terpieces of Poussin, Piero della Francesca, and Cézanne? Only one answer seems possible - significant form. In each lines and colours combined in a particular way, certain forms and relations of forms stir our aesthetic emotions. These relations and combinations of lines and colours, these aesthetically moving forms, I call 'Significant form'; and 'Significant form' is the one quality common to all works of visual art (Bell, 1987:7-8).

In an apparently inductive approach Bell comes to the conclusion that what really matters in at least the visual arts are the combination and relation of formal elements in such a way that they affect the observer in a specific - aesthetic way. If we attend closely to the matter of formal elements, and read it as Bell's answer to a lamentable cultural situation, his apparently inductive reasoning sounds convincing. What Bell is reacting against, as is well known, is the way in which art, especially paintings and sculpture, has become consumed in his time. There was "an excessive concern with subject matter" (Dickie, 1955:143): fashionable paintings and sculpture in England at the turn of the century were always 'about' something, and the skills of the artist and his use of materials were secondary to the portrayal of a subject, to a certain extent taken for granted. One can speak of the demands of an art market which set an index for works of art as commodity articles which favoured themes, topics and subjects. One can list the art of W.P. Frith (1819-1909), Sir L. Alma-Tadema (1836-1912) and Sir L. Filde (1844-1927), all referred to by Bell and classified (and disqualified) as 'Descriptive Painting' (Bell, 1987:16), as paradigm cases in this regard.

Against this background Bell's stress on the formal elements of a work of art makes sense. His argument focuses on the specifically artistic qualities of a work of art: the exploration of the possibilities of the artistic medium, a heightened sensitivity for the so-called techmical aspects of a work of art, the strikingness of a work of art irrespective of its subject (a painting about a humdrum subject can be very striking whereas the lumdrum subject in itself is not). Bell (1987:27) states it pointblank:

To appreciate a work of art we need bring with us nothing but a sense of form and colour and a knowledge of three-dimensional space. That bit of knowledge, I admit, is essential to the appreciation of many great works, since many of the most moving forms ever created are in three dimensions.

To put it in more recent terminology: somelow a work of visual art refers back to itself - the 'artiness' of a work of art fascinates us, and not so much its subject. If we have to choose between Cézanne's rendition of apples and that of the art school's novice, we - according to Bell - will always choose Cézanne, because Cézanne's painting is more significant than that of the art school's novice. With that Bell underscores the aesthetically significant. 
That seems to make sense. We should, however, bear in mind the shift in focus underlying this argument. What Bell says about art, is one thing; what he does about it, another. With 'significant form' Bell does not merely define the essence of art, but also implies a distinction between 'significant art' and 'insignificant art' - a distinction which is argued at great length. Bell is not really speaking of 'all art' as his argument apparently states. A closer inspection of his store room for works of art bears this out: the inclusion of crafts ("a Persian bowl, Chinese carpets") in the class of 'high' works of art such as the "masterpieces of Poussin, Piero della Francesca, and Cézanne", as well as the cross-cultural collection of artistic objects appears to be very ecumenical, but is in fact a careful selection to witness to the 'fact' of 'significant form'. What Bell omits is very telling. The art of the Renaissance and its aftermath during the seventeenth, eighteenth and early ninenteenth century are specifically excluded from the lineage from Byzantine art to Cézanne. According to Bell "all that did happen [during this period from the fifteenth to the early nineteentl century] was nothing more than a change from late manhood to early senility complicated by a house-moving, bringing with it new hobbies and occupations. ... A Renaissance picture was meant to say just those things that a patron would like to hear. That way lies the end of art ..." (Bell, 1987:162-163). About Rembrandt Bell is willing to concede that he may "perhaps [be] the greatest genius of them all", but then one also has to take into account that "genius-worship is the infallible sign of an uncreative age" (ibid.: 161), and therefore Rembrandt "is a typical ruin of his age. For, except in a few of his later works, his sense of form and design is utterly lost in a mess of rhetoric, romance, and chiaroscuro" (ibid.: 172).

What does Bell's lineage of significant art seem to say? To his contemporaries Bell's juxtaposition of Cézanne with Piero della Francesca might have sounded odd, if not outrageous. But he is playing an intellectual trick, apparently backed up by art historical knowledge. Bell delivers an eloquent apology of the new and unthought of so far by pointing to the so-called fact that the outrageous has its respected but long-forgotten forerunners. Cézanne is portrayed in this defense as picking up the golden thread that has been lost for some time. He reinstates the good tradition - of 'significant form'. More important, however, is that Bell conflates significant form and significant art, the aesthetically significant and the art historically significant.

Are we any closer now to the meaning of 'significant form'? When is a form 'significant'? Given Bell's conflation of the possible meanings of significant form, the problem is not so much how to recognize form, but how to recognize its significance. And when a significant form has been recognized and identified, what exactly has been recognized and identified? 


\subsection{Two kinds of significance}

The close reading of Bell so far seems to suggest that 'significant form' implies two meanings:

\subsubsection{The 'formal' qualities of a work of art}

The 'formal' qualities of a work of art imply the interplay of lines, colours, shapes, textures, surfaces and spaces. Bell seems to be content with the mere observation or awareness that there happens to be this interplay. What exactly is effected by this interplay of 'formal' elements, for instance what it 'says' or 'communicates' and how it comes about to 'say' or 'communicate', remains obscure - even in the account Bell gives of this effect, viz. the "stirring of emotions'. However, to recognize these formal elements requires very little from the 'emotions' as some 'deeper' way of knowing art. Bell's judgement of Rembrandt and Poussin attests to this: the striking features of some of Rembrandt's later works are his 'sense of form and design', and on Poussin Bell's judgement even amounts to a prescription:

For instance, in the best works of Nicolas Poussin, the greatest artist of the age, you will notice that the human figure is treated as a shape cut out of coloured paper to be pinned on as the composition directs. That is the right way to treat the human figure; the mistake lay in making these shapes retain the characteristic gestures of Classical rhetoric' (ibid.: 173).

'Significant forn' in this sense refers to the spatial organization of shapes in colerence with the other qualities of the artistic material, viz. colour, tone and texture. The implied prescription that 'shapes' should be unburdened by 'characteristic gestures of Classical rhetoric' suggests that significant form means visually striking and strong form. constituted by the artistic qualities of the material the artist employs. 'Significant' here does not suggest non-discursive meaning which can be rendered lexicographically by approximation. There is no 'dictionary' of significant forms, only approximate descriptions of visually striking relations of the qualities of artistic material. Representation is specifically excluded from significant form:

[I]f a representative form has value, it is as form, not as representation. The representative element in a work of art may or may not be hannful; always it is irrelevant (ibid.:25).

To reiterate: Bell's concept of significant form leads us toward an awareness of the use of rudimentary artistic material. 


\subsubsection{Art historical sense}

There is a second sense in which 'significant form' is used, which I shall call the art historical sense. A mere descriptive category is not intended by this second use, but rather a term which signifies approbation: a quite readily observable change or break in style which, according to Bell, is for the better. This break appears to be something radically new, but on second (art historical) thoughts it is a mere "crest of a new movement destined and doomed inevitably to sink to deptlls undreamed of ..." (ibid.:123). The history of art is to be thought of as a succession of declines; each decline is to be likened to a "slope ... which lies between a great primitive morning, when men create art because they must, and that darkest hour when men confound imitation with art" (ibid.:122). A quite readily observable break in style, when it may lay claim to 'significance', is when an artist or a movement temporarily reverses the inevitable downward slope to recapture something of the 'great beginning'. Thus whatever 'significant form' may be, it is informed by what is regarded, especially by Bell, as the "great primitive moning". 'Significant form' should at least be compatible with a certain body of art historical knowledge, preferably of the Romantic kind which Bell espouses.

So the phrase significant form, as Bell employs it, is rather ambivalent. That does not necessarily disqualify it, although one must acknowledge that it is not so simple to use it as a key to all genume art as Bell alleges. In a way these two senses of the phrase significant form may complement one another: The visually striking is that which violently disturbs the conventional and boring, canonized painterly procedures. An aesthetics of significant form is the theoretical understanding and explanation of one of late modernisin's prime aesthetic phenomena, viz. the new. Significant form as a formalist aesthetic category is parasitic upon a body of art historical knowledge, and requires a certain minimum of comparative procedures according to an art historical canon, which in Bell's case demands only and formally a renewal of what has become superficial through repetition and sallow variation. The canon of significant art is instantiated by a repertoire of works of art accorded that status by the art historical insight of the art critic. In Bell's aesthetics the other possibility of the appearance of the new, viz. negation, is not considered, probably because it was not yet experienced as an issue. Negation would involve not only previous art forms, but ultimately art and its socially instituted role itself.

\subsection{The significance of form (1)}

The question about the grounds for the insight of the art critic as well as the specific repertoire used to back up the notion of significant form remains a nag- 
ging issue. To repeat the question: The problem is not so much how to recognize form, but how to recognize its significance. Bell's answer to this is most unsatisfactory, but, again, very revealing. Bell simply reverts to a long-standing tradition that the perception and recognition of works of art call for a special, if not elevated, faculty of the mind, namely the emotions, more specifically the aesthetic emotion. Actually, Bell settles this issue en passant as a logical prerequisite for his notion of significant form. I quote at length:

\begin{abstract}
The starting-point for all systems of aesthetics must be the personal experience of a peculiar emotion. The objects that provoke this emotion we call works of art. All sensitive people agree that there is a peculiar emotion provoked by works of art. ... This emotion is called the aesthetic emotion; and if we can discover some quality common and peculiar to all objects that provoke it, we shall have solved what I take to be the central problem of aesthetics (ibid.:7).
\end{abstract}

Bell flattens the antinomy of taste ('How can something as individual as a judgment of taste ever acquire the status of universal acquiescence?') by using an ad populum appeal to 'all sensitive people'. It is stated that works of art are known through a specific emotion, the aesthetic emotion. Bell does not bother to go into the details of an anatomy of this emotion, because - for obvious reasons, already stated in the eighteenth century - it simply cannot be done in a rationally convincing manner. Matters of sentiment, such as the awareness of beauty, cannot be treated with the same rigour as matters of fact, as Hume told us. But Hume showed us a way out. The aesthetic emotion can be identified through its observable effects on behaviour; well, almost. When one experiences the aesthetic emotion one loses oneself "in that infinitely sublime state of mind to which pure visual form transports" one (ibid.:31)

Art transports us from the world of man's activity to a world of aesthetic exaltation. For a moment we are shut off from human interests; our anticipations and memories are arrested; we are lifted above the stream of life (ibid.:25).

The end result of the "stirring of the aesthetic emotion" is "aesthetic rapture" (ibid.:18). What happens here is that Bell takes the eighteenth century's 'seventh sense', the organ for artistic taste, for granted (cf. Meager, 1955; Osborne 1955), and without belabouring the socio-cultural requisites for the proper exercise of that organ (as Hume for instance did), masks the inherent elitism of the modernist concept of taste by giving a metaphysical twist to the functioning of the aesthetic emotion. Taste, as a result of the aesthetic emotion, is not the exclusive domain derived from "an assembly of civilized men - men like [Hume] himself" (Gay, 1973:309). Instead of an autonomy for the sphere of commerce with the arts based on social or class distinctions, Bell opts for autonomy as exclusivity on metaphysical grounds (cf. Crowther, 1922; Fishman, 1963). 
The aesthetic mysticism to which Bell's account of the aesthetic emotion leads is an underpinning of his modernist and formalist approach to cleanse the commerce with works of art from so-called non-aesthetic interests. But it is also at loggerheads with the implied requisites of the term significant form as he implements it himself. The art historical knowledge which is supposed to back up the recognition of (historically) significant form in a work of art (as aesthetically significant form) has nothing mysterious or mystical about it. It is communicable, it can be conceptualized and it allows for comparison, which is clearly not the case with 'aesthetic rapture'. Significant form may, however, be reconciled with an irrational aesthetic mysticism if it is taken to be the awareness by way of the aesthetic emotion of the mere fornal aspects of a work of art, in the first sense outlined above (i.e. as aesthetically significant form). I doubt whether Bell would stick to such an 'empty' formalism for very long. Significant form in the sense Bell wants to understand it appeals too strongly to a justifiable knowledge of the history of art to be that esoteric and idiosyncratic. Bell may not quite be aware of the impact of his own reconstruction of the history of art on the initial exposition of his concept of significant form. Taken as an apparently inductive conclusion from a set of aesthetic emotional experiences, it seems to underscore the kind of formalism Eduard Hanslick espoused: form is in a certain sense its own content, it has no significance beyond itself (cf. Ahlberg, 1992:5-20).

Whatever the case may be, Bell's significant form is a response to a further issue concerning modernist art, i.e. the problem of the autonomy of a work of art. By opposing representation with significant form, and thereby somewhat overhastily excluding semantic meaning from visual art forms (which then is restored in part by the art historical significance of forms), the independence of the work of art from an art market or any immediate social function is, at least temporarily, secured. To bolster this autonomy, it is necessary to emphasize the 'true' general quality of all works of art and present it as a generally accessible characteristic of art. But behind this procedure another typically modernist strategy is hiding: significant form is only accessible to the art-historically educated who surreptitiously take their aesthetic experience as the standard of all aesthetic experience.

\section{Langer's reinterpretation of significant form}

It is on this point that Susanne K. Langer rehabilitates Bell's concept of significant form. She underpins it with an epistemology which one may regard as a precursor of postmodernist opemness. As she states it herself:

[T] he only stumbling block which has held up the progress of ... 'significant form ' has been, I think, a lack of understanding of the ways in which logical structures may enter into various types of 'significance' (Langer, 1973:218). 
Taking the lead from Bell and at the same time disclaiming his tendency towards a 'purist' formalism (Langer, 1973:cf. 236-7), she opens up the theoretical scope of significance by suggesting a variety of types of significance. At the same time the aesthetic experience is relocated: whereas Bell tried to take the late modern use of the 'ugly' and the visually disconcerting seriously by focussing on the arthistorical significance of form in Cézanne's paintings by relating them to early 'primitivist' painting, but settling the embarrassing hybrid of aesthetic understanding uncomfortably in the traditional domain of the gratification of the senses, Langer treats significant form as something which has an inherent logic: the 'logic' of analogy, encompassing the senses, the intellect and language, by which it acts as a means to conceive of something.

Langer's reworking of the notion of significant form is taken up here exactly for this reason: her approach offers wider epistemological scope than does Bell's. Bell neglects the issue of how one comes to know the significance of form. And there is no need to enter into a detailed genealogy of Langer's thoughts to explore the viability of her solution.

Langer's treatment of significant form also points to an awareness of the qualities of artistic material as a prerequisite for getting acquainted with works of art intelligibly. Her argument, however, does not call for a tacit kind of knowledge as is the case with Bell's art-listorically reconstructed repertoire. The argument is instantiated by empirical psychological studies on the reception of musical sounds, and sounds convincing within the boundaries of music. The point then remains: how does one talk about significant form in the other arts? How could one generalize a formalist theory of artistic material in order to be applicable to the other arts?

\subsection{The significance of form (2)}

Let us first consider Langer's argunent for the significance of form in music. Relying on the findings of a psychological study of the "many aspects that enter into the notion of musical significance ... in ways that fairly well exclude nonmusical factors such as personal associations with tunes, instruments, styles ..., or programmatic suggestions" (ibid.229), the significance of (a) musical sound is portrayed as follows: "the lowest stage of tone-apprehension yields merely an impression of tone-color of the whole tonal complex, or of a difference between tone-colors of the separate tones" (ibid:229), together with a sense of the duration of intervals between tones experientially "translated" as "width of tonal intervals". This lays the foundation for a succession of meaning constitutive perceptions by the listener. As soon as the listener perceives a difference in tonal colours, an awareness of "tonal movement" and consequently of "musical direction" follows. The joint awareness of tonal distance and direction leads to the 
perception of a "musical step", which is the prerequisite for an anticipation of the following step, or an imagining of the previous step. This manifests itself in a sense for "consonance, dissonance and relatedness", i.e. a scale or tonic, which in turn "determines the feeling of modality". Langer concludes:

The entire study shows effectively how many factors of possible expressive virtue are involved in even the simplest musical structure, how many things beside the acknowledged materials of composition have crucial functions in conveying a musical message (ibid.:231).

The exact point of Langer's analysis is to demonstrate how the perception of certain inherent qualities or characteristics of the musical material is and becomes related to analogous perceptions gained from other spheres of experience, and how meaning or sense is imputed in a sublingual fashion from one known perception to another, to make sense out of the other.

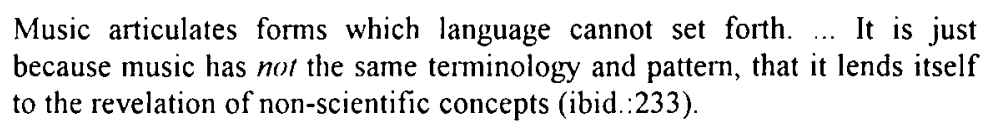

Given this distinction and limitation, it then makes sense to speak of "music as a semantic of vital and emotional facts" (ibid.235), "for what music can actually reflect is only the morphology of feeling" (ibid.:238)

\section{2 "An unconsummated symbol"}

This certainly is a big lump to swallow - especially when Langer refers explicitly to Bell:

Therefore music is 'Significant form', in the peculiar sense of 'significant' which Mr. Bell and Mr. Fry maintain they can grasp, or feel, but not define; such significance is implicit, but not conventionally fixed (ibid::241).

Perhaps Langer allows herself too much liberty in defining significance if one concedes readily the gap which at least Bell has left her. But I would not object too much at such a 'creative misunderstanding'. Implicit in Bell's use of the term significant form and in Langer's exposition of it is the notion of 'reading' a painting or a composition/performance. If Bell's concept of significant form does not include an allusion to semantics, it can be maintained that the implicit notion of reading is contained in his version of significant form by the activity of art historical comparison which supports it. Something similar goes for Langer: it is the sublingual, subconscious activity of comparing and relating the different aspects of sound which gives rise to it attaining some sense. Langer is careful to distinguish artistic meaning from the kind of meaning Bell disqualified as 'descriptive'. Artistic meaning is symbolic meaning which does not invite us to 
to deal with something by evoking an emotional response. Symbolic meaning leads us to "insight", to "conceive" of something (ibid :223). This is best understood when the traditional logical distinction between denotation and connotation is also taken into account. A musical form does not denote a specific mood in the sense that it is a necessary expression of the mood of the composer at the time of the composition, or a mood of that kind expressed through music and in some way recognizable by an audience. Langer maintains that

\begin{abstract}
music has all the earmarks of a true symbolism, except one: the existence of an assigned connotation. It is a form that is capable of connotation, and the meanings to which it is amenable are articulations of emotive, vital, sentient experiences. But its import is never fixed. [F]or music at its highest, though clearly a symbolic form, is an unconsummated symbol. Articulation is its life, but not assertion; expressiveness, not expression. The actual function of meaning, which calls for permanent contents, is not fulfilled; for the assignmient of one rather than another possible meaning to each form is never explicitly made (ibid.:240).
\end{abstract}

In order to get the gist of Langer's attempt at reliabilitating Bell's concept of significant form, one should bear in mind the modernist genealogy of the concept of art. If one takes Kant as one of the major contributors to this concept, one thing that one should never ignore is Kant's insistence on art as a form of knowledge or cognition. From a postmodern standpoint one could read Kant's notion of the aesthetic idea ('that representation of the imagination which induces much thought, yet without the possibility of any definite thought whatever, ... and which language, consequently, can never get quite on level terms with or render completely intelligible' [Kant, 1968:417 - my own translation]) as a built-in safeguard to the project of modenity, viz. the founding of rational knowledge counterpointed by an alternative discourse, the domain of the aesthetic, for the sake of human freedom. The sense of allowing such a domain to exist would be to allow for meaning that escapes logical and scientific rigour, and that in itself amounts to allowing for an alternative rationality. Langer's idea of a work of art as an unconsummated symbol lies half-way between Kant's aesthetic idea and Derrida's idea of erasure or postponing the closure of interpretation indefinitely. If one bears this in mind it is possible to extend Langer's vindication of formalism through music to other spheres of art. Music is not the formalist art par excellence because the meaning or content of the musical form is unfixed and never explicit (except, of course, for musical imitations of bird calls and the like, or for so-called programme music). The same is true of poetry and painting. Although poets may use words whose meaning can be looked up in a dictionary, the total meaning of the words in a poem is not exactly, if at all, constituted by lexicographically standardized denotations. The sounds of the words, their adventitious qualities, their placement in the verse - all contribute to the meaning of the poem. A famous example for formalist poetical reading is Theodor Stonn's "Die Stadt": 


\begin{abstract}
Am grauen Strand, am grauen Meer
Und seitab liegt die Stadt;

Der Nebel drückt die Dächer schwer,

Und durch die Stille braust das Meer

Eintönig um die Stadt.
\end{abstract}

The meaning of those first two lines is not contained in the exact denotations of the words, but in the unusual placement and inversion of abseits. The conventional usage would have been: Und die Stadt liegt abseits. Bringing abseits to a more accentuated position in the line and changing it to seitab is to allude sublingually to a sense of displacedness and abandonment.

\title{
4. Conclusion
}

If one can 'formalize' this explanation, it can be said that formalism as an artistic and an aesthetic practice is the conveying and conceiving of meaning through non-discursive means. The major linge of formalisin in this sense is the identification of contrasts and tensions and their resolutions through the exploitation of a constellation of artistically activated qualities of what is traditionally understood as the artist's medium, viz. pigments (painting), voluminous matter (sculpture), words (literature), sound (music), movement (dance). But formalism can go one step further: what has traditionally been taken as the form of a work of art, e.g. the 'sonnet form', the 'sonata form', still life or landscape painting or portraiture, etc., also becomes 'formalized' or conventionalized. Its features are generalized, and, once established through discursive formulation, reworked in artistic practice as a frame of reference, or a number of 'clues' 'which induces much thought' exactly in the sense of the Kantian aesthetic idea, or a horizon of expectations for its deciphering. When the consciousness of forn has achieved this stage, it changes its function from 'recipe' to critical instrument for artist and critic, and thereby it paves the way for its own dissolution. This does not mean the end of art, but, at least for the time being, the recycling of forms in all its dimensions.

\section{Bibliography}

AHLBERG, Lars-Olof 1992. Formalism and Music. (In Formalism 2. International Colloquium. Ljubljana : The Slovenian Society for Aesthetics. p. 5-20.)

BELL, Clive 1987. Art. Edited by J.B. Bullen. Oxford : Oxford University Press.

BRYSON, N., HOLLEY, M.A. \& MOXEY, Keith eds. 1991. Visual Theory, Painting and Interpretation. Cambridge : Polity Press.

CROWTHER, Paul 1992. Formalism in Art History: Its Philosophical Scope and Limits. (In Formalism 2. International Colloquium. Ljubljana : The Slovenian Society for Aesthetics. p. 28-38.)

DANTO, Arthur C. 1981. The Transfiguration of the Commonplace. A Philosophy of Art. Cambridge (Ma.) : Harvard University Press 
DICKIE, George T. 1955. Clive Bell and the Method of Principia Ethica. British Journal of Aesthetics, 5:139-143

FISHMAN, Solomon 1963. The Interpretation of Art. Essays on the Art Criticism of John Ruskin, Walter Pater, Clive Bell, Roger Fry and Herbert Read. Los Angeles : University of California Press.

GAY, Peter 1973. The Enlightenment - an Interpretation. Vol. 2: The Science of Freedom. London : Wildwood House

GOODMAN, Nelson 1976. Languages of Art. Indianapolis : Hackett Publ. Co.

KANT, Immanuel 1968. Werke. Band 8: Kritik der Urteilskraft und Schriften zur Naturphilosophie. Darmstadt : Wissenschaftliche Buchgesellschaft.

KIVY, Peter 1980. The Corded Shell. Reflections on Musical Expression. Princeton : Princeton University Press.

LANGER, Susanne K. 1973. Philosophy in a New Key. A Study in the Symbolism of Reason, Rite, and Art. Cambridge (Ma) : Harvard University Press.

MEAGER, R. 1955. Clive Bell and Aesthetic Emotion. British Journal of Aesthetics, 5:123131

OSBORNE, Harold 1955. Alison and Bell on Appreciation. British Journal of Aesthetics 5:132-138 
